\title{
Effects of Weeding Regimes on Prevalence and Rigidness of Viral Diseases on Okra (abelmoscus esculentus l. Moench) Performance
}

\author{
Abdulraheem Mukhtar Iderawumi ${ }^{1 *}$ and Moshood Abiodun Yusuff ${ }^{2}$ \\ ${ }^{1}$ Department of Agricultural Science Education, The College of Education, Lanlate, Oyo State, Nigeria \\ ${ }^{2}$ University of Ilorin, Kwara State, Nigeria \\ *Corresponding Author: Abdulraheem Mukhtar Iderawumi, Department of Agricultural Science Education, The College of Education, \\ Lanlate, Oyo State, Nigeria.
}

Received: June 20, 2019; Published: August 06, 2019

DOI: $10.31080 /$ ASAG.2019.03.0596

\begin{abstract}
Okra is susceptible to a large range of insect pests and diseases despite its importance in the economy and usefulness in any nation. Various growth stages of the crops are susceptible to the different insect pests and diseases. And these may militate against yield optimization if not properly managed. Hence this study aimed at carrying out the effects of different weeding regimes in prevalence and rigidness of okra (Abelmoscus esculentus L. Moench) viruses diseases and performance. There were twelve treatment combination replicated three times in a Randomised Complete Block Design (RCBD). The treatments were 3 X 4 factorial with each of the block divided into three plots measuring $9 \mathrm{~m} \mathrm{X} 5 \mathrm{~m}$ with okra planted at $60 \mathrm{~cm}$ by $90 \mathrm{~cm}$ at one plant per stand after thinning. Weeding was at four levels i.e. weeding thrice, weeding twice, weeding once and zero weeding (control). Plant heights, number of leaves, number of flowers, number of fruits, number of diseased fruits and yield were collected from 3WAP. The initial soil analysis shows that the surface soil at the experimental site was marginal in organic matter (OM), adequate in Nitrogen, Calcuim, Magnesium and Potassium but inadequate in Phosphorus and slightly acidic. A treatment combination of weeding thrice was found to be effective in the reduction of viral diseases percentage on prevalence and rigidness of okra on the field. However, considering the cost of insecticide, rigours in preparing disease free dry grasses mulch and tedious back-breaking weeding is affordable with at least twice weeding regime to strike balance and enhance okra production.
\end{abstract}

Keywords: Okra (Abelmoscus esculentus L. Moench); Virus; Weeding; Prevalence; Rigidness

\section{Introduction}

Okra (Abelmoschus esculentus L. Moench) is a member of the family Malvaceae and is a popular vegetable of considerable value. It is a widely cultivated vegetable of nutritional importance that provides essential components of the daily food intake in most rural and urban areas, and contributes to the nutritional balance of the diet. It is among the most commonly cultivated vegetables throughout Nigeria and other tropical regions because of its much liked mucilaginous or 'draw' property of the fruit and its ability to grow well under most tropical conditions [1].

Okra is also important protective food for the maintenance of health and prevention of disease. It contains valuable food ingredients, which can be successfully utilized to build up and repair the body $[2,3]$. It is also valuable in maintaining alkaline reserve in the body and valued mainly for their high vitamin and mineral con- tent [3]. In facts, Okra is one of the most important vegetable crops grown for its tender leaves, fruit and fibrous stem [4].

Okra requires a long, warm and humid growing period. It can be successfully grown in hot humid areas. It is sensitive to frost and extremely low temperatures [5]. For normal growth and development a temperature between $24^{\circ} \mathrm{C}$ and $38^{\circ} \mathrm{C}$ is preferred [6]. This higher position is not necessarily accompanied with a delay in time because at higher temperatures the plants grow faster and the higher position is reached earlier [6]. For faster plant growth still, higher temperature helps though it delays the fruiting [6].

Okra cultivation and production has been widely practiced because of its importance to the economy development and can be found in almost every market in Africa (AVRDC, 2004). 
Furthermore, Okra mucilage is suitable for medicinal and industrial applications. It has medically food application as a plasma replacement or blood volume expander. Industrially, okra mucilage is usually used in glaring certain papers and also useful in confectionery among other uses [7].

Different control methods/ techniques have been employed to reduce virus diseases prevalence on cultivated okra. According to Tropical Advisory Services (2002), measures highlighted as follows are meant to help in preventing and controlling virus diseases.

Healthy plants: take seeds and cuttings from healthy plants. New crop from healthy seeds or cuttings should always be planted. Where possible, only seeds certified as virus free should be planted.

Dip cuttings in mixture of wood ash and water to prevent diseases some plant varieties are resistant or immune to viruses. Although some modern varieties may be resistant to specific diseases, they may not be suited to local conditions. Recommended varieties can be resistant to disease and suited to local conditions.

\section{Role of mulching in weed management}

Reduce weed growth and clean crop: By providing a physical barrier, mulching reduces the germination and nourishment of many weeds. The mulching operation favours in the reduction of weed seed germination, weeds growth and keeps the weed under control [8]. Covering or mulching the soil surface can prevent weed seed germination or physically suppress seedling emergence.

Loose materials such as straw, bark and composted municipal green waste can provide effective weed control [9]. Saw dust is a soil improver and weed suppressor as it conserves soil moisture, decreases run-off, increases infiltration and percolation, decreases evaporation hand weed growth can be substantial under clear mulch [10].

White or clear mulch and green covering had little effect on weeds, whereas brown, black, blue or white on black (double color) films prevented emerging weeds [11]. Ossom., et al. [12] also observed significant differences in weed control between mulched and unmulched plots of eggplant.

The objectives are to evaluates the main effects of weeding regimes on the prevalence and determination of virus diseases of okra; to evaluate the effect of treatment combinations weeding regimes\} on the prevalence and determination of virus diseases of okra under field condition.

\section{Materials and Methods}

Field experiments was carried out at the Teaching and Research Farm of the University of Ilorin, Kwara State, Nigeria. The area lies between the savannah, between latitude $80.291 \mathrm{~N}$ and $90301 \mathrm{~N}$ and longitude $40301 \mathrm{E}$ and $60251 \mathrm{E}$. The rain fall pattern of Ilorin is bimodal with a wet season of about four months occurring from June to October and with a brief dry spell, which in most cases occur in the second half of August. Annual average minimum and maximum temperatures are $26^{\circ} \mathrm{C}$ and $49^{\circ} \mathrm{C}$ respectively. The mean relative humidity is about $75 \%$. The soil at the site is classified as an alfisol (Oxic tropuldalf) according to Adepetu., et al [13]. There were twelve treatment combination replicated three times in a Randomised Complete Block Design (RCBD). The treatments were $3 \mathrm{X}$ 4 factorial with each of the block divided into three plots measuring $9 \mathrm{~m} \mathrm{X} 5 \mathrm{~m}$ with okra planted at $60 \mathrm{~cm}$ by $90 \mathrm{~cm}$ at one plant per stand after thinning. Weeding was at four levels i.e. weeding thrice, weeding twice, weeding once and zero weeding (control). Plant heights, number of leaves, number of flowers, number of fruits, number of diseased fruits and yield were collected from 3WAP. Control of weeds was done by application of pre emergence herbicides: Force upTM (glyphosate) incorporated with StumpTM (malathion 60 EC). Subsequent weeding were done after okra emergence (2 weeks after planting) subsequent weeding were carried out manually base on the weeding regimes of the treatment combinations as stated earlier. All data were collected on a weekly basis on growths, yield and disease parameters as at when due in the morning and the record was maintained on the selected samples of the population in each that were already tagged. The diseased leaves obtained on the selected samples were counted and recorded start from 4 weeks after planting. The number of diseased fruits was obtained by counting the number of okra yields of selected sample plants of fresh harvest that showed almost $80 \%$ viral symptoms base on visual observation.

Surface $(0-15 \mathrm{~cm})$ soil samples were taken before the commencement of the experiments (initial soil analysis). Immediately after collection of surface soil samples using steel auger, samples were bulked for each year, air-dried and allowed to pass through $2 \mathrm{~mm}$ sieve for analysis as outlined by procedures of Tel and Hagarty [14]. Total N was determined by Kjedahl method (Jackson 1962), P by molybdenum blue colorimetry while K, Ca and Mg extracted with ammonium acetate $\mathrm{pH} 7.0$ extractant after which the exchangeable $\mathrm{K}$ was evaluated using flame photometer while $\mathrm{Ca}$ and Mg were evaluated by EDTA titration. Soil $\mathrm{pH}$ in water was determined using $\mathrm{pH}$ meter in 1: 2 soil water ratio medium. Organic carbon and organic matter was determined using Walkley Black dicromate method [15] as modified by Nelson and Sommer [16]. Data collected from 3 WAP includes; were plant heights, number of leaves, number of flowers, number of fruits, number of diseased fruits and yield. Data collected were subjected to analysis of variance (ANOVA). The means were separated using Duncan's Multiple Range Test (DMRT) using SPSS (statistics packages for social sciences). 


\section{Results and Discussion}

Analytical data of pre-cropping surface soil at the site of experiment are shown in table 1 . The test soil was marginal in organic matter (OM), adequate in Nitrogen, Calcuim, Magnesium and Potassium but inadequate in Phosphorus and slightly acidic [17]. Therefore the soil required application of fertilizing amendment that will particularly supply P for enhancing okra

\begin{tabular}{|l|c|}
\hline \multicolumn{1}{|c|}{ Properties } & Parameters \\
\hline $\mathrm{pH}\left(\mathrm{H}_{2} \mathrm{O}\right)$ & 6.50 \\
Organic Matter $\left(\mathrm{gkg}^{-1}\right)$ & 28.00 \\
Total nitrogen $(\mathrm{N}) \mathrm{gkg}^{-1}$ & 3.20 \\
Available phosphorous (P) (mg kg-1) & 8.80 \\
Exchangeable calcium (cmolkg-1) & 7.31 \\
Exchangeable magnesium (Mg) $\left(\mathrm{cmolkg}^{-1}\right)$ & 2.50 \\
Exchangeable potassium (K) $\left(\mathrm{cmolkg}^{-1}\right)$ & 0.30 \\
\hline
\end{tabular}

Table 1: Soil chemical properties.
At third week (table 2) after planting regime of no weeding had the highest percentage prevalence of $(14.23 \%)$ when compared among all the treatments but it was not significantly different from regime weeded once $(11.88 \%)$ while regime weeded twice $(8.03 \%)$ and weeded thrice $(6.52 \%)$ were not significantly different when compared together. However, regime weeded thrice had the lowest percentage prevalence among all the four regimes.

At the fourth week after planting, regime that was not weeded (25.61\%) had the highest percentage prevalence when compared with all the treatment levels while the regime weeded thrice had the lowest percentage prevalence (11.38\%).

An assessment of the results on the basis of weeding regimes showed that by the fifth week after planting, the regime that was not weeded had the highest percentage viral prevalence of 38.41, followed by the regime weeded once with a viral prevalence of 32.01 , regime weeded twice had the percentage prevalence of

\begin{tabular}{|l|c|c|c|c|c|}
\hline \multicolumn{1}{|c|}{ Weeding } & \multicolumn{5}{c|}{ Prevalence (\%) } \\
\hline No-weeding & 3WAP & 4WAP & 5WAP & 6WAP & 7WAP \\
\hline Once & $14.23 \mathrm{a}$ & $25.61 \mathrm{a}$ & $38.41 \mathrm{a}$ & $46.69 \mathrm{a}$ & $70.37 \mathrm{a}$ \\
\hline Twice & $11.88 \mathrm{a}$ & $21.38 \mathrm{a}$ & $32.01 \mathrm{a}$ & $38.61 \mathrm{a}$ & $59.48 \mathrm{~b}$ \\
\hline Thrice & $8.03 \mathrm{~b}$ & $14.45 \mathrm{~b}$ & $21.68 \mathrm{~b}$ & $28.12 \mathrm{~b}$ & $49.31 \mathrm{c}$ \\
\hline S.E & $6.52 \mathrm{~b}$ & $11.38 \mathrm{~b}$ & $16.41 \mathrm{~b}$ & $21.07 \mathrm{~b}$ & $41.55 \mathrm{c}$ \\
\hline
\end{tabular}

Table 2: Main effects of Weeding regimes on percentage prevalence of viral diseases on okra at different times after planting.

21.86 and the regime weeded thrice had the lowest viral prevalence of 16.41. A significant difference did not exist between the 2 weeding regimes not weeded and weeded once while the regime weeded twice and thrice are not significantly difference when compared with one another respectively.

The values had the same trend to the 6 th week where the regime weeded thrice had the lowest viral prevalence of 21.07, followed by weeded twice with a viral prevalence of 28.12 and the regime not weeded with the highest viral prevalence of 46.69 followed by regime weeded once of percentage prevalence of 38.61. It shows that no significant difference existed among the no-weeding and once weeding regimes when compared with each other and also no significant difference in the regime weeded twice when both were compared.
The values for week 7 , the regime weeded thrice had the lowest viral prevalence of 41.55 , followed by the regime weeded twice with a viral prevalence of 49.31 and the regime weeded once with the viral prevalence of 59.48 while the regime weeded once had the highest prevalence of 70.37. This shows that there was significant difference between the regimes not weeded and weeded once while there was no significant difference between weeded twice and the regime weeded thrice.

Table 3 shows the results of analysis of the main and interactive effect of weeding and mulching type regimes on percentage rigidness of okra. Considering at week 3 , the regime that was not weeded had the highest rigidness of $19 \%$, followed by the regime that was weeded once with a rigidness of $13.36 \%$ and regime weeded twice with rigidness $10.66 \%$ while the regime that was weeded thrice had lowest rigidness $9.5 \%$. Although there was no significant 
between the regimes weeded once and weeded twice and weeded thrice, there was significant difference in the regime that was not weeded when compare with others. At 4 week after planting, the highest percentage rigidness was recorded on regime that was not weeded (30.89\%), followed by regime weeded once (13.26\%), twice (16.94\%) and thrice (15.09\%). It implied that there was no significant between regime weeded once $(21.06 \%)$, regime weeded twice (16.94\%) and regime weeded thrice (15.09\%) but there was significant difference between regime of no weeding and any other weeding regimes.
At week 5, plants in the plots that were not weeded had the highest disease rigidness of $52.25 \%$, followed by the regime weeded once with a rigidness of $35.80 \%$ while the regime weeded twice had a rigidness of $28.80 \%$ and regime weeded thrice had the lowest rigidness of $24.69 \%$. It shows that there was a significant difference between the three weeding regimes compared with one another while weeding once, twice and thrice are not significantly different.

\begin{tabular}{|c|c|c|c|c|c|}
\hline \multicolumn{7}{|c|}{ Rigidness (\%) } \\
\hline Weeding regimes & 3WAP & 4WAP & 5WAP & 6WAP & 7WAP \\
\hline No-weeding & $19.35 \mathrm{a}$ & $30.89 \mathrm{a}$ & $52.25 \mathrm{a}$ & $67.47 \mathrm{a}$ & $83.94 \mathrm{a}$ \\
\hline Once & $13.26 \mathrm{~b}$ & $21.06 \mathrm{~b}$ & $35.80 \mathrm{~b}$ & $53.08 \mathrm{~b}$ & $70.36 \mathrm{~b}$ \\
\hline Twice & $10.66 \mathrm{~b}$ & $16.94 \mathrm{~b}$ & $28.80 \mathrm{~b}$ & $42.38 \mathrm{bc}$ & $60.89 \mathrm{bc}$ \\
\hline Thrice & $9.5 \mathrm{~b}$ & $15.09 \mathrm{~b}$ & $24.69 \mathrm{~b}$ & $39.50 \mathrm{c}$ & $53.90 \mathrm{c}$ \\
\hline S.E & 1.68 & 2.67 & 4.49 & 3.87 & 3.85 \\
\hline
\end{tabular}

Table 3: Main effects of Weeding regimes on percentage rigidness of viral diseases on okra at different times after planting.

Values with same letter(s) in a given segment of a column are not significantly different at probability level using New Duncan's Multiple Range Test (NDMRT). Key: S.E= Standard Error of Mean, WAP= Week After Planting

At week 6, the regime that was not weeded had the highest rigidness of $67 \%$, followed by the regime that was weeded once with a rigidness of $53.08 \%$ and regime weeded twice with rigidness 42.38 while the regime that was weeded thrice had lowest rigidness 39.50. A significant difference however did not exist between the regimes weeded thrice and weeded twice having a rigidness 39.50 and $42.38 \%$ respectively.

At week 7, the regimes that was not weeded had the highest rigidness of $83 \%$ followed by the regime weeded once with a rigidness of $70.36 \%$ and regime weeded twice with rigidness of $60.89 \%$ while the regime weeded thrice had a rigidness of $53.90 \%$. A sig- nificant difference occurred between regimes that was not weeded and that weeded once, significant difference also occurred between regimes that was weeded once and that weeded thrice.

Table 4 show the result of analysis of variance of main and interactive effect of weeding and mulching types on okra plant height. At third week after planting, the regime weeded thrice had the tallest plant height of $15.98 \mathrm{~cm}$ followed by regime weeded twice $(15.73 \mathrm{~cm})$, regime weeded once $(14.78 \mathrm{~cm})$ and regime that was not weeded had the shortest plant height. There was no significant difference among all the weeding regimes.

\begin{tabular}{|l|c|c|c|c|c|}
\hline \multicolumn{7}{|c|}{ Plant Height (cm) } \\
\hline \multicolumn{1}{|c|}{ Weeding } & 3WAP & 4WAP & 5WAP & 6WAP & 7WAP \\
\hline No-weeding & 14.65 & 21.48 & 32.22 & 34.00 & 37.63 \\
\hline Once & 14.78 & 21.68 & 32.52 & 34.78 & 39.44 \\
\hline Twice & 15.73 & 23.06 & 34.92 & 35.87 & 41.40 \\
\hline Thrice & 15.98 & 23.43 & 35.15 & 37.89 & 42.56 \\
\hline S.E & $0.66^{\mathrm{NS}}$ & $0.97^{\mathrm{NS}}$ & $1.45^{\mathrm{NS}}$ & $1.48^{\mathrm{NS}}$ & $1.95^{\mathrm{NS}}$ \\
\hline
\end{tabular}

Table 4: Main effects of Weeding regimes on plant height of okra plant at different times after planting.

Values with same letter(s) in a given segment of a column are not significantly different at probability level using New Duncan's Multiple Range Test (NDMRT).

Key: **=Significance, S.E= Standard Error of Mean, WAP= Week After Planting 
At 4th week after planting, the regime weeded thrice had the tallest plant height $(23.43 \mathrm{~cm})$ while the regime that was not weeded had the shortest plant height $(21.28 \mathrm{~cm})$. There was no significant difference when comparing the entire weeding regimes.

At week 5, the regime weeded thrice had the tallest plant height of 35.15, followed by the regime weeded twice with height of 34.92 while regime weeded once and no-weeding had 32.52 and 32.22 respectively. No significance difference was observed between the regimes either weeded no-weeding, once, twice, or thrice and in fact regimes weeded once and no-weeding are very close with slight difference of 0.30 .

At week 6, the regime weeded thrice had the highest plant height at 37.89 followed by the regime weeded twice with height of 35.87 and weeded once of height 34.78 while no weeded regime is 34.00. It shows that there is no significant difference between the four weeding regimes when compare with one another.

The values follow the same trend to the 7 th week, where the regime weeded thrice had the highest height of 42.56 , followed by regime weeded twice, once and no-weeding with heights: 41.40, 39.44 and 37.63 respectively. And also it was very obvious that there is no significant difference in the main effect of the plant height when compare with one another.

An assessment of the result on table 4a showed the main effect of weeding regimes and mulching types on prevalence of viral diseases on okra number of leaves at different times after planting.

An assessment based on the main effect of weeding regimes shows that at 3 weeks after planting the number of leaves are significantly different with plant weeded thrice having the highest leaves (6.33) followed by weeding twice regime (5.89 leaves) while plant weeded once and no-weeding weeded are not significantly difference with number of leaves (5.03) and (5.31) respectively. However, no-weeding weeded main effect has the lowest number of leaves.

An assessment based on the main effect of weeding regimes shows that at 4 weeks after planting the number of leaves are significantly different with plant weeded thrice having the highest leaves (9.28) followed by weeding twice regime (8.64 leaves) while plant weeded once and no-weeding weeded are not significantly difference with number of leaves (7.38) and (7.93) respectively. However, no-weeding weeded main effect has the lowest number of leaves.

An assessment based on the main effect of weeding regimes shows that at 5 weeks after planting the number of leaves are significantly different with plant weeded thrice having the highest leaves (13.93) followed by weeding twice regime (12.97 leaves) while plant weeded once and no-weeding weeded are not significantly difference with number of leaves (11.07) and (11.89) respectively. However, no-weeding weeded main effect has the lowest number of leaves.

At the sixth week the trend was the same pattern as 5 th week as plant weeded thrice was significantly difference with 16.85 leaves followed closely by weeding twice regime and weeded once and no-weeding weeding plants had 12.96 and 14.15 respectively.

At week 7, there was drastic reduction in the number of leaves on plant thereby no-weeding of the main effect of the weeding regimes whether thrice of number of leaves (6.56), weeding twice (5.63), weeding once (5.19) or non weeding (6.2) was significant. It was however observed that plant weeded thrice had the highest number of leaves followed by no-weeding weeding, twice and lastly plant weeded once had the lowest number of leaves.

\begin{tabular}{|l|c|c|c|c|c|}
\hline \multicolumn{7}{|c|}{ Number of leaves (cm) } \\
\hline Weeding regimes & 3WAP & 4WAP & 5WAP & 6WAP & 7WAP \\
\hline No-weeding & $5.31 \mathrm{~b}$ & $7.93 \mathrm{~b}$ & $11.89 \mathrm{~b}$ & $14.15 \mathrm{~b}$ & 6.22 \\
\hline Once & $5.034 \mathrm{~b}$ & $7.38 \mathrm{~b}$ & $11.07 \mathrm{~b}$ & $12.96 \mathrm{~b}$ & 5.19 \\
\hline Twice & $5.89 \mathrm{ab}$ & $8.64 \mathrm{ab}$ & $12.97 \mathrm{ab}$ & $15.15 \mathrm{ab}$ & 5.63 \\
\hline Thrice & $6.33 \mathrm{a}$ & $9.28 \mathrm{a}$ & $13.93 \mathrm{a}$ & $16.85 \mathrm{a}$ & 6.56 \\
\hline S.E & 0.29 & 0.42 & 0.63 & 0.74 & $0.84^{\text {NS }}$ \\
\hline
\end{tabular}

Table 5: Main effects of Weeding regimes on prevalence of viral diseases on okra Number of leaves at different times after planting.

Values with same letter(s) in a given segment of a column are not significantly different at probability level using New Duncan's Multiple Range Test (NDMRT).

Key: **=Significance, S.E= Standard Error of Mean, WAP= Week After Planting 
The table 6 under number of flowers showed that there was no significant difference in all the weeding regimes. However, regime weeded thrice produced the highest number of flowers of 7.15 while the regime weeded once has the lowest number of flowers of 5.78 .
Table 6 under the number of diseased fruits showed the main effect of weeding regime showed the analysis of the number of diseased fruits. The analysis on the basis of weeding regimes showed that there was no significantly difference between the numbers of diseased fruits. However, regime that was not weeded had the

\begin{tabular}{|l|c|c|c|}
\hline Weeding & No of flowers & No of edible fruits & No of diseased fruits \\
\hline No-weeding & 6.07 & $2.52 \mathrm{c}$ & 2.41 \\
\hline Once & 5.78 & $2.29 \mathrm{bc}$ & 2.11 \\
\hline Twice & 6.48 & $2.89 \mathrm{~b}$ & 2.22 \\
\hline Thrice & 7.15 & $3.48 \mathrm{a}$ & 1.80 \\
\hline S.E & $0.41^{\mathrm{NS}}$ & 0.18 & $0.18^{\mathrm{NS}}$ \\
\hline
\end{tabular}

Table 6: Main effects of Weeding regimes on prevalence of viral diseases on okra number of flowers, edible fruits and diseased fruits. Values with same letter(s) in a given segment of a column are not significantly different at probability level using New Duncan's Multiple Range Test (NDMRT).

Key: ${ }^{* *}=$ Significance, S.E $=$ Standard Error of Mean, WAP= Week After Planting

highest number of diseased fruits of 2.41 while the lowest numbers of diseased fruits were recorded on regime weeded thrice.

The table 6 under the number of edible fruit showed that the analysed result showed the main effect of the weeding regimes of the number of edible fruit produced whereby all the regimes are apparently significant to one another. However, regime weeded thrice had the highest number of number of edible fruits of 3.48 followed by 2.89 of regime weeded twice and 2.52 of regime not weeded while regime weeded one has the lowest number of edible fruits of 2.29 .

Table 7 showed the main effects of Weeding regimes on prevalence of viral diseases on okra fresh yield. The weeding regime weeded thrice had the highest weight of fresh yield of $40.02 \mathrm{~g}$ that is significantly different from regime weeded twice of mass $35.74 \mathrm{~g}$ while regime non weeded and weeded once are not significantly difference with fresh weight of 34.39 and 34.13 respectively.

\section{Discussion and Conclusion}

On the basis of these results, it can be concluded that reduction in the density of weeds significantly positively caused reduction in the prevalence and rigidness of viral diseases. Weeding regime significantly influenced prevalence and rigidness of viral diseases on okra. Weeding at least twice significantly reduced the prevalence and rigidness of viral diseases on okra. This was probably due to less space for harbouring vectors and reduced spatial competition with crops.

\begin{tabular}{|l|c|}
\hline \multicolumn{1}{|c|}{ Weeding } & Okra Fresh Yield (g) \\
\hline No-weeding & $34.39 \mathrm{~b}$ \\
\hline Once & $34.13 \mathrm{~b}$ \\
\hline Twice & $35.74 \mathrm{ab}$ \\
\hline Thrice & $42.02 \mathrm{a}$ \\
\hline S.E & 2.46 \\
\hline
\end{tabular}

Table 7: Main effects of weeding regimes on prevalence of viral diseases on okra fresh yield.

Values with same letter(s) in a given segment of a column are not significantly different at probability level using New Duncan's Multiple Range Test (NDMRT).

Key: ${ }^{* *}=$ Significance, S.E $=$ Standard Error of Mean, WAP= Week After Planting

Furthermore, this study also showed that yield reduction was due to uncontrolled weed growth in okra estimated 58.6-68.8\% compared to the regime that was weeded twice and thrice. This finding is in agreement with the works of Katung and Kashina [18] who reported that yield losses due to parasitic weeds range from $50-80 \%$ and 41-80 respectively. In addition, weeding removes competition for space by crops and giving crops physiological boost [19].

More so, the study also showed that a treatment combination of polythene mulching and weeding thrice produced highest yield parameters. This suggests that weeding could be effective in viral 
disease control, it is better determined on polythene mulch. Polythene mulching significantly influenced prevalence and rigidness of viral infection on okra. Polythene mulching combined with at least weeding twice significantly reduced the prevalence and rigidness of viral diseases. Significant reduction was probably a result of reduced vector population which could have served to transmit the viruses responsible for infection.

Within the limit of this trial therefore, a treatment combination of weeding thrice was found to be effective in the reduction of viral diseases percentage on prevalence and rigidness of okra on the field. However, considering the cost of insecticide, rigours in preparing disease free dry grasses mulch and tedious back-breaking weeding is affordable with at least twice weeding regime to strike balance and enhance okra production.

\section{Bibliography}

1. Eke KA., et al. "Determination of Optimum Planting Time of okra (Abelmoschus esculantus) cultivars in the derived Savannah". Proceedings of the 42nd Annual Conference of Agricultural Society of Nigeria (ASN). October 19th to 23rd at Ebonyi State University (2008): 242-245.

2. Bakhru HK. "Foods that heal. The Natural way to good health". Orient paperbacks Delhi (2003): 82-90.

3. Edet GE and Etim NA. "Gender Role in fluted Pumpkin (Telferia Occidentalis) production in Akwa Ibom State". Proceeding of the 41st Annual Conference of the Agricultural society of Nigeria (ASU) held at Zaira, 22nd-26th (2007): 612-615.

4. Bamire AS and Oke JT. "Profitability of vegetable farming under rainy and dry season production in Southwestern Nigeria". Journal of Vegetable Crop Production 9 (2003): 11-18

5. Purohit K., et al. "Effect of mulches on soil temperature, soil moisture, growth and yield of Okra during winter and rainfed condition in West Bengal". Indian Journal of Sericulture 29 (2000): 64-71.

6. Diaz-Perez., et al. "Effect of plastic mulches on root zone temperature and on the manifestation of tomato spotted wilt symptoms and yield of tomato". Science Horticulture 114 (2007): 90-95.

7. Arapitsas P. "Identification and quantification of polyphenolic compounds from okra seeds and skins". Food Chemistry 110 (2008): 1041-1045.

8. Vander Zaag., et al. "Response of solanum potatoes to mulching during different seasons in an isohyperthemic environment in the Philippines". Tropical Agriculture (Trinidad) 63 (2006): 229-239.
9. Merwin I., et al. "Comparing mulches, herbicides and cultivation as orchard groundcover management systems". Hort. Technology 5 (2005): 151-158.

10. Waterer DR. "Effect of soil mulches and herbicides on production economics of warm season vegetable crops in a cool climate". HortTechnology 10 (2000): 154-159.

11. Bond W and Grundy AC. "Non-chemical weed management in organic farming systems". Weed Research 41 (2001): 383-405.

12. Ossom E., et al. "Effect of mulch on weed infestation, soil temperature, nutrient concentration, and tuber yield in Ipomoea batatus (L.) Lam". In Papua New Guinea. Tropical Agriculture (Trinidad), 78 (2001): 144-151.

13. Adeputu JA., et al. "Preliminary survey of the fertility status of soils in Ondo State under traditional cultivation". Ife Journal of Agriculture 1 (1979): 134-139.

14. Tel DA and Hagarty M. "Soil and Plant Analysis". IITA/University of Guelph. (1984): 277.

15. Walkey A and Black IA. "An examination of the Degtajareff Method for determining Organic Matter and proposed Modification of the Chromic Acid Titration Method". Soil Science 37 (1934): 29-38.

16. Nelson DW and Sommer LE. "Total C and organic matter in Methods of soil Analysis". Part 2. Chemical and Micrbiological Properties. Winscosin A. L (Ed). 2nd edition ASA and SSSA. Madison WI (1982): 539-579.

17. Akinrinde EA and Obigbesan GO. "Evaluation of fertility status of selected soil for crop production in five ecological zones of Nigeria". Proceeding 26th Annual Conference of Soil Science Society of Nigeria, Ibadan (2000): 279-288.

18. Katung MD and Kashina BD. "Time of partial Defoliation and GAS Effect on Growth Indices and yield of okra (Abelmoschus esculantus (L) Moench)". Proceeding Of the 39th Annual Conference of the Agricultural Society of Nigeria (ASN) held at Benin, 9th-13th October (2005): 210-213.

19. Sugiyarto M. "The effect of mulching technology to enhance the diversity of soil macro invertebrates in sengon based agroforestry systems". Biodiversitas 10 (2009): 129-133.

\section{Volume 3 Issue 9 September 2019 (C) All rights are reserved by Mguidich Belhaj A., et al.}

